\title{
Indicador Estatístico Salarial
}

Pedro Marcondes Machado*

Este comentário visa a divulgar a técnica utilizada por uma emprêsa de consultoria em administração de pessoal, ao elaborar um informe estatístico salarial. Duas vêzes por ano, uma em abril e outra em outubro, essa emprêsa levanta índices sôbre 36 posiçóes entre as mais altas de uma hierarquia empresarial.

O trabalho resulta tão-sòmente do processamento dos cartões perfurados, os quais contêm informaçóes prestadas pelos executivos entrevistados.

Para a organização dêsse trabalho, partiu-se do organogramapadrão de uma emprêsa hipotética, inspirado nos esquemas das grandes indústrias norte-americanas, onde se pretende apenas identificar as áreas de supervisão, a posição do supervisor e as formas de relações entre êste e as demais posiçóes. $O$ organograma serve, portanto, para posicionar o profissional que se apresenta para cadastro. As designações dos cargos dêsse organograma são modelos. Os dados, cujo levantamento estatístico permitiu analisar as qualificações necessárias ao melhor desempenho de cada função, foram incluídos nos textos descritivos dos

- Gerente da Morris \& Morgan - Consultores e Engenheiros Associados, São Paulo.

R. Adm. Emp., Rio de Janeiro, 10(4): 235-237, out./dez. 1970 
respectivos cargos. Os benefícios adicionais, que são características próprias de cada emprêsa, estão mencionados nas descrições dos cargos.

Para encontrar a moda salarial de cada posição, procurou-se, inicialmente, construir o histograma de distribuição dos profissionais por idade. Com os grupos etários mais freqüentes construiu-se outro gráfico, relacionando o salário atual de cada profissional com o respectivo tempo de experiência no cargo.

O valor de salário chamado moda, considerado para cada cargo, corresponde ao baricentro da amostra dos grupos etários mais freqüentes.

Foram considerados, nessa estatística, sòmente os profissionais ligados a emprêsas cujo faturamento não seja inferior a Cr $\$ 1.500 .000,00$ mensais.

O quadro-resumo indica para cada posição: a faixa de idade pesquisada, a moda de experiência em anos no cargo, a moda de salário mensal e o salário máximo de registro em poder da emprêsa de consultoria em administração de pessoal. Nas duas últimas colunas do quadro foram consideradas as possíveis remunerações mensais reais, quando acrescidas das bonificações.

Tomando como exemplo o Gerente de Vendas - cargo comum em tôdas as emprêsas - a estatística nos diz que o grupo etário mais frequiente se situa entre as idades de 26 e 50 anos, a experiência no cargo em tôrno de 5 anos, a moda salarial da posição em $\operatorname{Cr} \$ 4.300,00$ e a remuneração real mensal em $\operatorname{Cr} \$ 5.000,00$.

\begin{tabular}{|c|c|c|c|c|c|c|}
\hline \multirow{2}{*}{ Cargo } & \multirow{2}{*}{$\begin{array}{l}\text { Limites de } \\
\text { Idade do } \\
\text { Amostragem } \\
\text { (enos) }\end{array}$} & \multirow{2}{*}{$\begin{array}{c}\begin{array}{c}\text { Experiência } \\
\text { no Cargo } \\
\text { (anos) }\end{array} \\
\text { moda }\end{array}$} & \multicolumn{2}{|c|}{$\begin{array}{l}\text { Salário } \\
\text { Menss! } \\
\text { (Cr\$ } 1.000)\end{array}$} & \multicolumn{2}{|c|}{$\begin{array}{l}\text { Rermuneraç5o } \\
\text { Real Mensal } \\
\text { (Cr } 1,000)\end{array}$} \\
\hline & & & moda & max. & $\begin{array}{c}\text { moda }+ \\
\text { bont. }\end{array}$ & $\begin{array}{c}\max .+ \\
\text { bonif. }\end{array}$ \\
\hline $\begin{array}{l}\text { Gerente Geral } \\
\text { Gerente Comercial } \\
\text { Gerente de Vendas }\end{array}$ & $26-50$ & 5 & 4.3 & 7.2 & 5.0 & 9.06 \\
\hline
\end{tabular}

De acôrdo com o exposto, pode-se constatar que o informe estatístico, em virtude de sua objetividade, se torna de grande valia ao empresário na busca de informações sôbre os cargos executivos de sua própria emprêsa. 
Figura 1 Histograma de Distribuição dos Profissionais Cadastrados na Posição Gerente de Vendas (por idade do profissional, em abril de 1970)

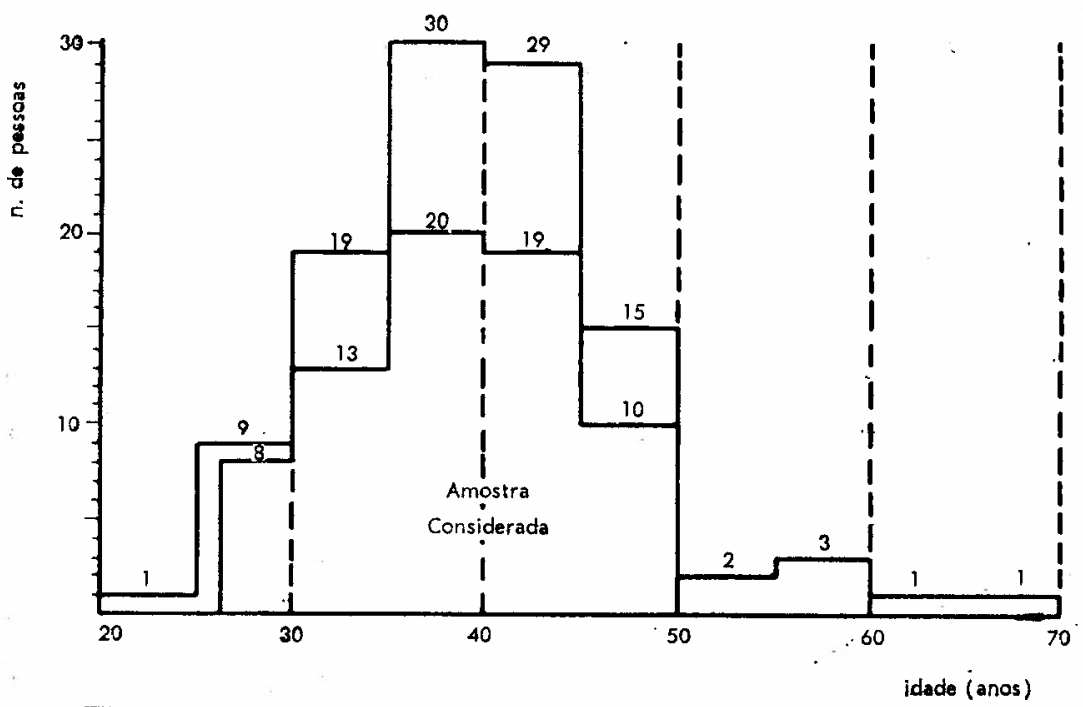

Figura 2 Determinação da Moda Salarial da Posição Gerente de Vendas

(O gráfico relaciona o salário declarado e a experiência no cargo, em abril de 1970)

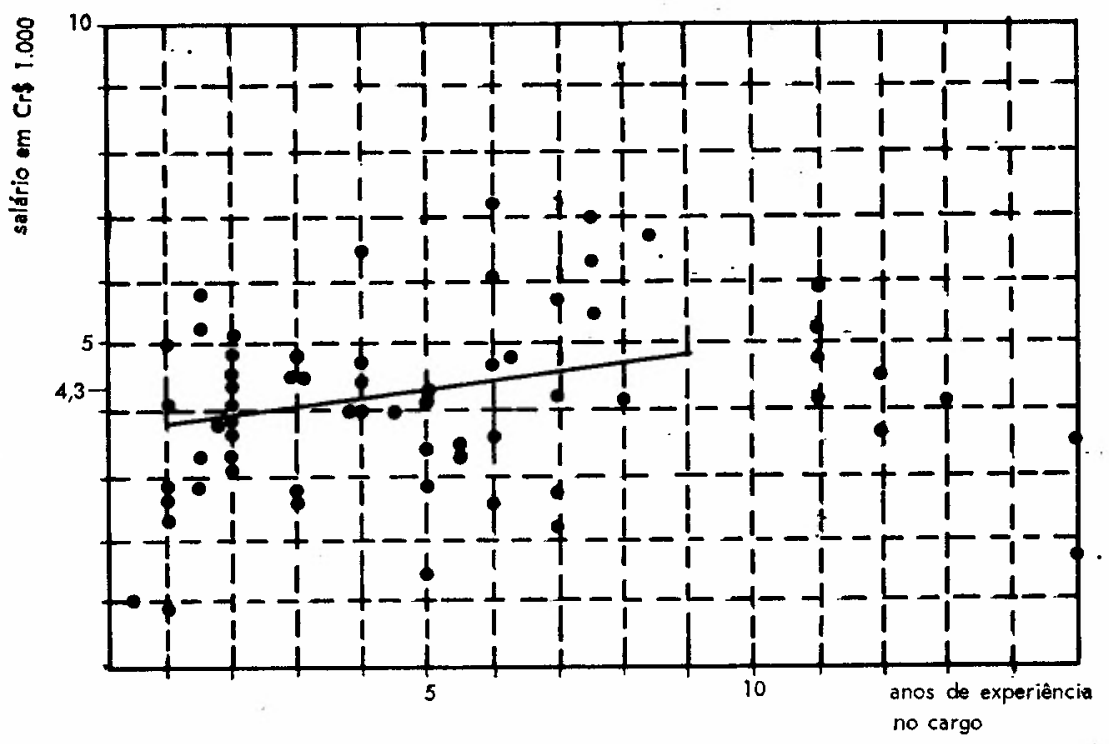

